\title{
Analysis of aminopeptidase and dipeptidylpeptidase IV from the entomopathogenic fungus Metarhizium anisopliae
}

\author{
Raymond J. St Leger ${ }^{1 *}$, Richard M. CoOper ${ }^{2}$ and A. Keith Charnley ${ }^{2}$ \\ ${ }^{1}$ Boyce Thompson Institute for Plant Research, Tower Road, Cornell University, Ithaca, NY 14853-1801, USA \\ ${ }^{2}$ Department of Crop Protection, School of Biological Sciences, University of Bath, Claverton Down, Bath, \\ Avon $B A 27 A Y, U K$
}

(Recieved 27 July 1992; revised 16 October 1992; accepted 29 October 1992)

\begin{abstract}
Analytical and preparative isoelectric focusing were used to separate extracellular isoenzymes of aminopeptidase (pI 4.51, $M_{\mathrm{r}}$ 45000, pH optimum 7.0) and prolyl-dipeptidylpeptidase (pI 4.01, $M_{\mathrm{r}}$ 74000, pH optimum 8.0) produced by the entomopathogenic fungus Metarhizium anisopliae during growth on locust cuticle. Production of both activities is repressed by readily utilized nitrogen sources, but unlike the aminopeptidase, the dipeptidylpeptidase was also excreted at high levels during growth on casein. Casein-grown cultures contained additional isoenzymes with activity against lysyl-alanyl-4-methoxy-2-naphthylamine indicating $M$. anisopliae possesses multiple peptidases as an adaptation to different nutrient conditions. The aminopeptidase hydrolysed alanyl-leucyl-alanine and showed a broad specificity versus monoaminoacyl $\beta$-naphthylamine ( $\beta$ NA) substrates with alanine $\beta$ NA being the most rapidly hydrolysed. Inhibition by both bestatin and amastatin indicated similarities to the class of alanyl aminopeptidases (aminopeptidase $M$ ). Metal complexing agents also inhibited the aminopeptidase indicating a metal ion requirement. A specific inhibitor for serine proteases [diisopropyl fluorophosphate (DFP)] was without effect. The dipeptidylpeptidase showed a strong preference for substrates having a penultimate proline residue including alanyl-prolyl-glycine and aa-prolyl- $\beta$ NA substrates. The enzyme showed a broad specificity at the N-terminal amino acid. Inhibition by diprotin $\mathbf{A}$ indicates similarities with mammalian prolyl-dipeptidylpeptidases. The enzyme was also inhibited by DFP, implying involvement of a serine residue in catalysis. The results are discussed in the context of cuticle degradation and the participation of exopeptidases as mediators in releasing amino acids necessary for pathogen growth.
\end{abstract}

\section{Introduction}

The proteolytic activity of the fungal entomopathogen Metarhizium anisopliae enables penetration of the proteinaceous cuticular barrier of insects (Goettel et al., 1989; St Leger et al., 1987a, 1988a,b). The first step in proteolysis has been shown to be catalysed by an extracellular chymoelastase protease $(\operatorname{Pr} 1)$ that constitutes the major protein product synthesized by $M$. anisopliae infection structures (St Leger et al., 1989, 1992). The action of Pr1 on the cuticle releases peptides

*Author for correspondence. Tel. (607) 254 1370; fax (607) 254 1242.

Abbreviations: aa, amino acid; Ben, benzoyl; Suc, succinyl; Z, $N$-benzyloxycarbonyl; MNA, 4-methoxy-2-naphthylamine; $\beta \mathrm{NA}$, $\beta$-naphthylamine; $p \mathrm{NA}, p$-nitroaniline; DFP, diisopropyl fluorophosphate; FBB, fast blue B (tetrazotized diorthoanisidine); IEF, isoelectric focusing; $\mathrm{MM}, 0.1 \% \mathrm{KH}_{2} \mathrm{PO}_{4}, 0.05 \% \mathrm{MgSO}_{4} ; \mathrm{Prl}$, chymoelastase protease of $M$. anisopliae; $\mathrm{Pr} 2$, trypsin-like protease of $M$. anisopliae; SDB, Sabouraud dextrose broth. with a mean residue length of five (St Leger et al., 1986a, $b$ ), which may be further degraded and rendered available for uptake and metabolism by exopeptidases produced during penetration. In this context, we detected high aminopeptidase activity on mature appressoria (St Leger et al., 1987b). The preference of the enzyme for alanyl rather than leucyl histochemical substrates was considered noteworthy as alanine is the major amino acid component of insect cuticle and supports better growth of $M$. anisopliae than other amino acids (St Leger et al., 1986c). More recently, we found that aminopeptidases were produced by several unrelated entomopathogenic fungi during growth on insect cuticle, implying a ubiquitous function for these enzymes (Samuels et al., 1990). In view of the potential importance of aminopeptidases in the hydrolysis of cuticle peptides and the provision of nutrients, we have studied the properties of the enzyme from $M$. anisopliae.

The Prl enzymes of five species of entomopathogenic fungi show similar discrimination by their $S_{3}, S_{2}$, and $S_{1}$ 
subsites against proline (St Leger et al., 1987a,c). Proline constitutes $10 \%(\mathrm{w} / \mathrm{w})$ of total amino acid residues in locust cuticle (St Leger et al., 1986a) suggesting that one or more peptidases capable of hydrolysing peptide bonds involving proline will be necessary to complement $\operatorname{Pr} 1$ for complete hydrolysis of cuticle proteins and maximum cell growth. One such enzyme is prolyl dipeptidylpeptidase (dipeptidylpeptidase IV; EC 3.4.14.5), which releases $\mathrm{N}$-terminal dipeptides from polypeptides containing proline in the penultimate position. The enzyme has been characterized from mammalian systems (Imai et al., 1983), several bacteria (Khalid \& Marth, 1990), and Saccharomyces cerevisiae (Alvarez et al., 1985). This communication reports the partial characterization of an extracellular prolyl dipeptidylpeptidase in culture filtrates of $M$. anisopliae and compares its activity with the aminopeptidase.

\section{Methods}

Organisms and growth. The fungal isolate ( $M$. anisopliae ME1), culture media, and preparation of locust cuticle were described by $\mathrm{St}$ Leger et al. (1986a).

Chemicals. All amino acids used were $\mathrm{L}$ configuration unless otherwise stated. Ala- $p \mathrm{NA}$, (Ala) $)_{2}-p \mathrm{NA},(\text { Ala })_{3}-p \mathrm{NA}$, Suc-(Ala) $)_{3}-p \mathrm{NA}$, Gly-Pro- $p$ NA, Suc-(Ala) $)_{2}$-Pro-Phe- $p$ NA, Ben-Phe-Val-Arg- $p$ NA, GlyPro-MNA, Lys-Ala-MNA, Ala-MNA, Leu-MNA, Met-MNA, monoaminoacyl $\beta$ NA substrates, Ala-Leu-Ala and Ala-Pro-Gly were from Sigma. Other peptide derivatives of $\beta$ NA or MNA were supplied by Bachem. Pure grade FBB was from Serva, Sephadex G-100 fine and Ampholines were from Pharmacia. Other chemicals used were commercial products of analytical grade.

Analytical isoelectric focusing (IEF). Filtrates from four-day-old cultures grown on $1 \%$ casein/basal salts or $1 \%$ locust cuticle/basal salts media (St Leger et al., 1987a) were dialysed $\left(14 \mathrm{~h}\right.$ at $4{ }^{\circ} \mathrm{C}$ with 200 vols distilled water, $\mathrm{pH} 6, M_{r}$ cut-off 6-8000) and concentrated ten-fold in a dialysis bag surrounded by polyethylene glycol $\left(M_{\mathrm{r}}\right.$ 20000). Concentrated filtrates $(20 \mu \mathrm{l})$ were applied using paper strips to Ampholine PAG plates, pH 3.5-9.5 (LKB, Bromma, Sweden). The electrofocusing was performed using an LKB 2117 Multiphor apparatus for $90 \mathrm{~min}$ according to the manufacturer's instructions. Afterwards, gel plates were divided into the required portions, rinsed in $2 \mathrm{mM}$-potassium phosphate buffer $(\mathrm{pH} 7)$ for $15 \mathrm{~s}$ and incubated at $25^{\circ} \mathrm{C}$ for up to $2 \mathrm{~h}$ in fresh buffer containing peptidase substrates (monoaminoacyl and peptide derivatives of MNA at $1.5 \mathrm{~mm}$ ) and Fast Blue $\mathbf{B}\left(1 \mathrm{mg} \mathrm{m}^{-1}\right)$. Enzymes were indicated by red bands. This procedure using MNA derivatives is a modification of the histochemical techniques we used previously to localize cuticle-degrading enzymes on infection structures (St Leger et al., 1987b).

Enzyme purification. Filtrates from four-day-old cultures grown on $1 \%$ locust cuticle/basal salts containing aminopeptidase (vs Ala- $\beta$ NA) and dipeptidylpeptidase (vs Gly-Pro- $\beta$ NA) were dialysed and concentrated with polyethylene glycol before ammonium sulphate precipitation and fractionating by IEF [LKB $8101110 \mathrm{ml}$ column, pH range $3 \cdot 5-10 \cdot 0$, as described by St Leger et al. (1986a)]. Enzyme activities in the eluate were determined after removal of ampholytes using Amicon (Danvers, MA) Centricon-10 ultrafiltration units. Fractions containing the highest levels of each activity were applied separately to a Sephadex G-100 fine column $(60 \times 2.5 \mathrm{~cm})$ (Pharmacia) equilibrated with $0.15 \mathrm{M}$-potassium phosphate buffer at $\mathrm{pH} 6.5$ (St
Leger et al., 1986a). Molecular mass estimations were based on elution volumes (Andrews, 1964) of the following marker proteins: ribonuclease $\left(M_{\mathrm{r}} 13700\right)$, chymotrypsinogen A $\left(M_{\mathrm{r}} 25000\right)$, ovalbumin $\left(M_{\mathrm{r}} 43000\right)$, albumin $\left(M_{\mathrm{r}} 67000\right)$, and aldolase $\left(M_{\mathrm{r}} 158000\right)$. Removal of contaminating trypsin-activity $(\operatorname{Pr} 2)$ from the dipeptidylpeptidase was achieved by passage through an affinity column of soybean trypsin inhibitor-Sepharose prepared and used as described previously (St Leger et al., 1987a).

Enzyme assays. Except where stated, aminopeptidase and dipeptidylpeptidase were assayed at $\mathrm{pH} 7$ and $\mathrm{pH} \mathrm{8,} \mathrm{respectively.} \mathrm{Prl} \mathrm{activity}$ vs Suc-(Ala) ${ }_{2}$-Pro-Phe- $p$ NA or Pr 2 activity vs Ben-Phe-Val-Arg- $p$ NA were assayed as described by St Leger et al. (1987a). Likewise, activity against Suc-(Ala) $)_{3}-p \mathrm{NA}$, Ala- $p \mathrm{NA},(\mathrm{Ala})_{2}-p \mathrm{NA},(\mathrm{Ala})_{3}-p \mathrm{NA}$ and GlyPro-pNA were assayed in reaction mixtures containing $0.1 \mathrm{ml}$ enzyme and $1.8 \mathrm{ml}$ substrate ( $1 \mathrm{mM}$ in Britton-Robinson Universal buffer). Results are expressed as nmol or $\mu \mathrm{mol} p \mathrm{NA}$ released $\mathrm{ml}^{-1} \mathrm{~min}^{-1}$. Aminopeptidase activity (vs monoaminoacyl $\beta$ NA substrates) or dipeptidase activity (vs peptide $\beta$ NA substrates) were assayed in reaction mixtures containing $0.1 \mathrm{ml}$ enzyme and $1 \mathrm{ml}$ of substrate ( $1 \mathrm{~mm}$ in Britton-Robinson Universal buffer), as described by St Leger et al. $(1986 c)$. Activity units are expressed as $\mu \mathrm{mol} \beta \mathrm{NA}$ released $\mathrm{ml}^{-1}$ $10 \mathrm{~min}^{-1}$. Enzyme activities towards peptides (Ala-Pro-Gly and AlaLeu-Ala) were assayed in a reaction mixture containing $1.8 \mathrm{ml}$ substrate ( $1 \mathrm{~mm}$ in $10 \mathrm{~mm}$ phosphate buffer), and $0.2 \mathrm{ml}$ purified enzyme incubated at $30^{\circ} \mathrm{C}$, the $\alpha$-amino groups released were measured with Cd-ninhydrin (Method C) (Doi et al., 1981). The results are expressed as $\mu \mathrm{mol}$ glycine equivalents released $\mathrm{ml}^{-1} \mathrm{~h}^{-1} . N$ acetylglucosaminidase activity (vs $p$-nitrophenyl- $N$-acetyl- $\beta$-D-glucosamine) was assayed as described by St Leger et al. (1986c). Activity units are expressed as nmol $p$-nitrophenol released $\mathrm{ml}^{-1} \mathrm{~h}^{-1}$.

All controls contained autoclaved enzyme $\left(121^{\circ} \mathrm{C}\right.$ for $\left.30 \mathrm{~min}\right)$ in place of unheated enzyme solutions.

Transfer experiments. Standardized mycelial inocula ( $5 \mathrm{~g}$ wet $\mathrm{wt}$ ) from $48 \mathrm{~h}$ SDB cultures (St Leger et al., 1991) were incubated with shaking (100 r.p.m.) for $8 \mathrm{~h}$ in $50 \mathrm{ml}$ sterile $\left(120^{\circ} \mathrm{C}, 15 \mathrm{~min}\right)$ basal media $(0.1 \%$ $\mathrm{KH}_{2} \mathrm{PO}_{4}, 0.05 \% \mathrm{MgSO}_{4}, \mathrm{pH}$ 6) alone (MM) or supplemented with carbon and/or nitrogen sources at $0 \cdot 2-1 \%(\mathrm{w} / \mathrm{v})$. Cultures were buffered at $\mathrm{pH} 6$ with MES (St Leger et al., 1986c). For some experiments, cultures were inoculated with conidia $\left(3 \times 10^{6}\right)$ and incubated for up to $4 \mathrm{~d}$.

Permeabilization experiments. Mycelial inocula $(5 \mathrm{~g}$ wet $\mathrm{wt}$ ) were transferred to fresh SDB media or $1 \%$ chitin/MM for $8 \mathrm{~h}$. The mycelium was washed with $0.7 \mathrm{M}$-sorbitol $(3 \times 50 \mathrm{ml})$, collected by centrifugation $(1000 \mathrm{~g}, 10 \mathrm{~min})$ and made permeable by suspending in $10 \mathrm{ml} 0.7 \mathrm{M}$-sorbitol, adding $1 \mathrm{ml}$ toluene/ethanol (1:4 by vol.) and shaking the suspension vigorously for $5 \mathrm{~min}$ at room temperature (Hirsch et al., 1988).

\section{Results}

\section{Analytical electrofocusing}

One major band and four minor bands could be distinguished when aminopeptidase activity in cuticle grown cultures was tested with Ala-MNA (Fig. 1). The substrates Leu-MNA and Met-MNA gave similar zymograms with regard to the number and focusing of the bands, but bands obtained with Ala-MNA were far more intense. Incubation of gels with any two of these substrates simultaneously resulted in the same pattern of bands, confirming that activities vs these monoaminocyl substrates were due to the same enzymes. No bands were 


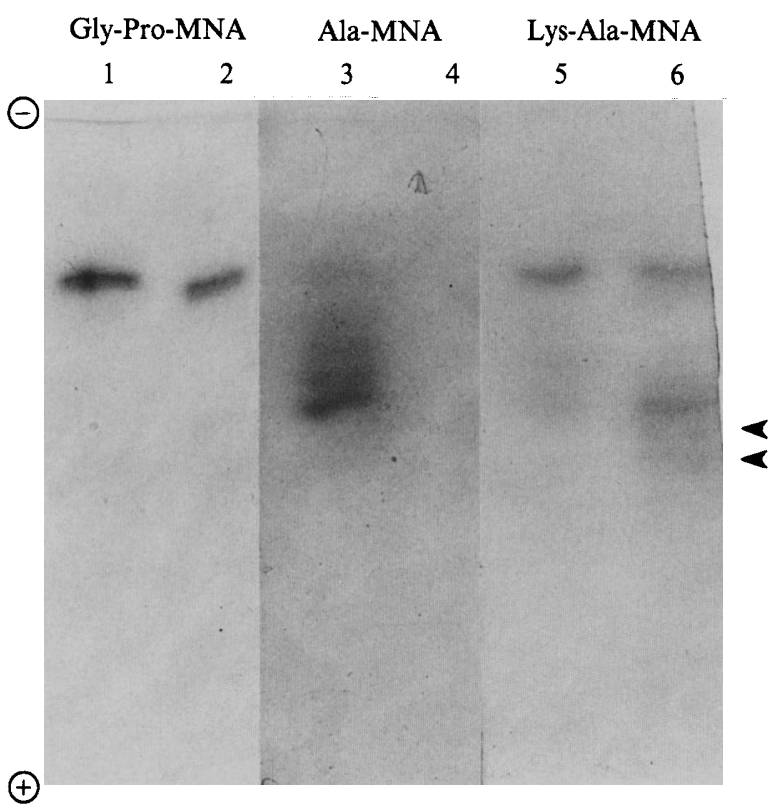

Fig. 1. Isoelectric focusing of cultures grown on $1 \%(\mathrm{w} / \mathrm{v})$ locust cuticle (lanes 1, 3, and 5) or $1 \%(\mathrm{w} / \mathrm{v})$ casein (lanes 2, 4, and 6) and band development with the dipeptidylpeptidase IV substrate Gly-Pro-MNA (lanes 1 and 2), the aminopeptidase M substrate Ala-MNA (lanes 3 and 4) and the dipeptidylpeptidase II substrate Lys-Ala-MNA (lanes 5 and 6). Additional bands vs Lys-Ala MNA are indicated by arrowheads. The results are typical of at least three similar experiments using different enzyme preparations.

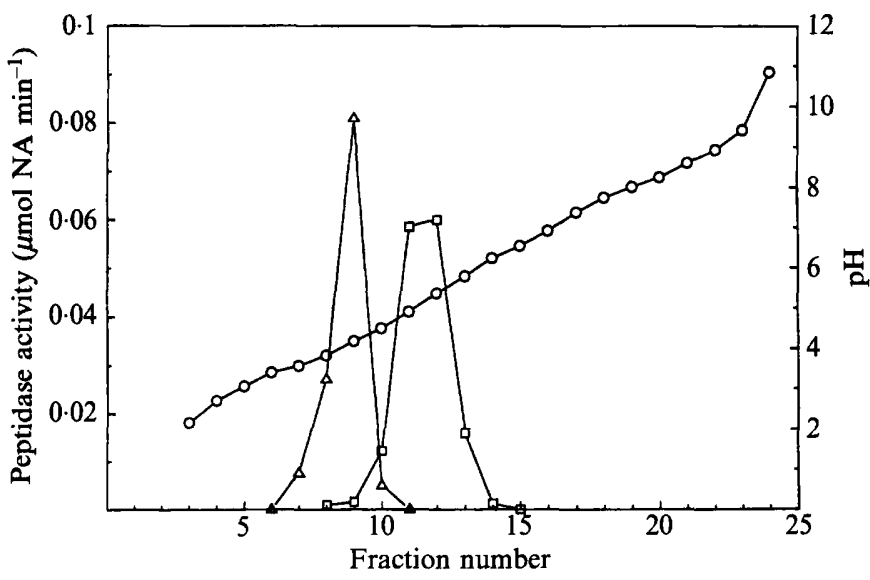

Fig. 2. Isoelectric focusing ( $\mathrm{pH} \mathrm{3-10)} \mathrm{of} \mathrm{peptidases} \mathrm{in} \mathrm{cuticle} \mathrm{culture}$ filtrate. The experiment was performed in a $110 \mathrm{ml}$ column for $48 \mathrm{~h}$ at $300-1000 \mathrm{~V}$ with the cathode at the top of the column. Fractions $(4 \mathrm{ml})$ were collected, $\mathrm{pH}$ was determined $(O)$ and activity vs Ala- $\beta$ NA $(\square)$ and Gly-Pro- $\beta$ NA $(\triangle)$ was assayed in each fraction.

detected using Pro-MNA as substrate. Zymograms of filtrates from casein grown cultures revealed no bands with Ala-MNA (Fig. 1).

Zymograms stained with the dipeptidylpeptidase IV substrate Gly-Pro-MNA (Gossrau, 1985) revealed two closely spaced bands (Fig. 1) which also stained with Phe-Pro-MNA (not shown). Both bands focused separately from the major aminopeptidase activity and were

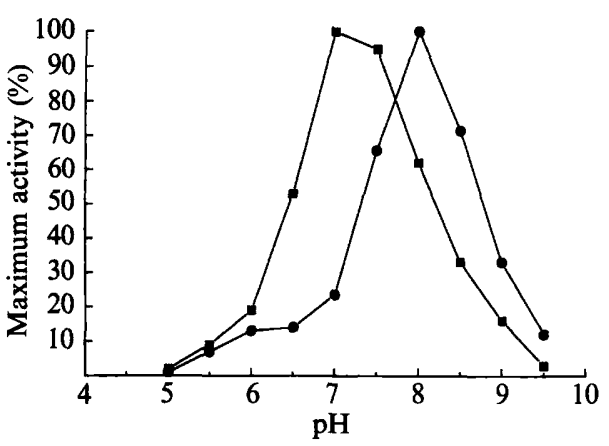

Fig. 3. Determination of $\mathrm{pH}$ optimum of aminopeptidase ( $\square$, vs Ala$\beta$ NA) and dipeptidylpeptidase (O, vs Gly-Pro- $\beta$ NA) using BrittonRobinson buffer (pH range 4.5-9.5).

Table 1. Specificity of aminopeptidase and dipeptidylpeptidase against $\beta N A$ substrates

$M$. anisopliae peptidases were partially purified and assayed as described in the text. The maximum aminopeptidase and dipeptidylpeptidase activities corresponding to $100 \%$ were $22 \cdot 8 \pm 0.32$ units $(\mathrm{mg} \text { protein })^{-1}$ and $34.5 \pm 0.34$ units (mg protein) ${ }^{-1}$, respectively, for 3 replicates $\pm S D$.

\begin{tabular}{lcc}
\hline \hline & \multicolumn{2}{c}{ Relative activity (\%) } \\
\cline { 2 - 3 } Substrate & Aminopeptidase & Dipeptidylpeptidase \\
\hline L-Ala- $\beta$ NA & 100 & $<0 \cdot 1$ \\
D-Ala- $\beta$ NA & 0 & 0 \\
$\beta$-Ala- $\beta$ NA & 0 & 0 \\
Ser- $\beta$ NA & 51 & $<0 \cdot 1$ \\
Val- $\beta$ NA & 41 & $<0 \cdot 1$ \\
Gly- $\beta$ NA & 34 & $<0 \cdot 1$ \\
Arg- $\beta$ NA & 19 & $<0 \cdot 1$ \\
Phe- $\beta$ NA & 18 & $<0 \cdot 1$ \\
Leu- $\beta$ NA & 15 & $<0 \cdot 1$ \\
Asp- $\beta$ NA & 3 & $<0 \cdot 1$ \\
Pro- $\beta$ NA & 1 & $<0 \cdot 1$ \\
Gly-Pro- $\beta$ NA & $0 \cdot 3$ & 100 \\
Z-Gly-Pro- $\beta$ NA & 0 & 0 \\
Phe-Pro- $\beta$ NA & $0 \cdot 2$ & 57 \\
Gly-Phe- $\beta$ NA & $0 \cdot 5$ & 3 \\
Arg-Arg- $\beta$ NA & $0 \cdot 1$ & 5 \\
Lys-Ala- $\beta$ NA & 1 & 2 \\
\hline \hline
\end{tabular}

of equal intensity in filtrates from cuticle and casein grown cultures. By contrast, staining of gels with the dipeptidylpeptidase II substrate Lys-Ala-MNA (Lojda, 1985) revealed weak co-reaction with the aminopeptidase and dipeptidylpeptidase IV bands. However, two more basic bands were observed in casein grown culture filtrates (Fig. 1).

\section{Partial purification of $M$. anisopliae peptidases}

Peptidase activity in culture filtrates was resolved into aminopeptidase (pI 4.31) and dipeptidylpeptidase (pI 4.01) components. These enzymes could be distinguished by their activities towards substrates Ala- $\beta$ NA and Gly- 
Table 2. Effect of inhibitors on aminopeptidase and dipeptidylpeptidase activities

The rate of hydrolysis of Ala- $\beta$ NA and Gly-Pro- $\beta$ NA in the absence of any inhibitor $\left(0.5 \mu \mathrm{mol} \beta \mathrm{NA} \mathrm{ml} l^{-1}\right.$ $10 \mathrm{~min}^{-1}$ ) was taken as $100 \%$. Values for the actual residual activities, in $\mu \mathrm{mol} \beta \mathrm{NA} \mathrm{ml}^{-1} 10 \mathrm{~min}^{-1}$, are given in parentheses ( 3 replicates \pm SD).

\begin{tabular}{|c|c|c|c|}
\hline \multirow[b]{2}{*}{ Reagent } & \multirow{2}{*}{$\begin{array}{l}\text { Preincubation } \\
\text { time (h) }\end{array}$} & \multicolumn{2}{|c|}{ Residual activities (\%) } \\
\hline & & Aminopeptidase & Dipeptidylpeptidase \\
\hline Buffer alone & 1.0 & 100 & 100 \\
\hline 1,10-phenanthroline (1 mM) & $1 \cdot 0$ & 0 & 94 \\
\hline DFP (1 mM) & $0 \cdot 5$ & 100 & $7(0.035 \pm 0.005)$ \\
\hline PMSF (0.2 mM) & $1 \cdot 0$ & 100 & $74(0.37 \pm 0.02)$ \\
\hline Amastatin $\left(50 \mu \mathrm{g} \mathrm{ml}^{-1}\right)$ & 1.0 & $68(0.34 \pm 0.03)$ & 100 \\
\hline Bestatin $\left(50 \mu \mathrm{g} \mathrm{ml}^{-1}\right)$ & $1 \cdot 0$ & $73(0.37 \pm 0.03)$ & 100 \\
\hline Diprotin A $\left(50 \mu \mathrm{g} \mathrm{ml}^{-1}\right)$ & 1.0 & 96 & $22(0 \cdot 11 \pm 0 \cdot 02)$ \\
\hline
\end{tabular}

Table 3. Peptidase production by $M$. anisopliae

Peptidase production was assayed $8 \mathrm{~h}$ after transfer of growing mycelium to cultures containing either a carbon and nitrogen source or nutrient limiting conditions. Mean aminopeptidase activity (vs Ala-pNA), dipeptidase activity (vs Gly-Pro-pNA) and Prl activity (vs Suc-(Ala) ${ }_{2}$-Pro-Phe-pNA) are given for 3 replicates \pm SD. The results are representative of two similar experiments.

\begin{tabular}{lccc}
\hline \hline & \multicolumn{2}{c}{ Enzyme activity $\left(\mathrm{nmol}\right.$ nitroanilide $\mathrm{ml}^{-1} \mathrm{~mm}^{-1}$ ) } \\
\cline { 2 - 4 } Addition & Aminopeptidase & Dipeptidylpeptidase & Pr1 \\
\hline None & $0 \cdot 2 \pm 0 \cdot 01$ & 0 & $10 \cdot 2 \pm 2 \cdot 3$ \\
$\mathrm{NH}_{4} \mathrm{Cl}(0 \cdot 4 \%)$ & 0 & 0 & $0 \cdot 2 \pm 0$ \\
Glucose $(1 \%)$ & $0 \cdot 1 \pm 0$ & $0 \cdot 01 \pm 0$ & $2 \cdot 2 \pm 0 \cdot 3$ \\
Cellulose (1\%) & $0 \cdot 2 \pm 0 \cdot 01$ & $0 \cdot 02 \pm 0 \cdot 01$ & $18 \cdot 7 \pm 2 \cdot 24$ \\
Locust cuticle $(1 \%)$ & $8 \cdot 3 \pm 0 \cdot 5$ & $0 \cdot 62 \pm 0 \cdot 04$ & $38 \cdot 7 \pm 3 \cdot 8$ \\
Elastin $(1 \%)$ & $11 \pm 0 \cdot 8$ & $0 \cdot 34 \pm 0 \cdot 03$ & $22 \cdot 4 \pm 1 \cdot 9$ \\
Casein (1\%) & $0 \cdot 5 \pm 0 \cdot 07$ & $0 \cdot 36 \pm 0 \cdot 03$ & $23 \cdot 6 \pm 2 \cdot 0$ \\
Ala (1\%) & $0 \cdot 2 \pm 0 \cdot 03$ & $0 \cdot 07 \pm 0 \cdot 013$ & $5 \cdot 3 \pm 0 \cdot 23$ \\
Leu (1\%) & $0 \cdot 15 \pm 0 \cdot 02$ & $0 \cdot 07 \pm 0 \cdot 015$ & $6 \cdot 8 \pm 0 \cdot 24$ \\
Gly-Pro $(1 \%)$ & $0 \cdot 1 \pm 0 \cdot 01$ & $0 \cdot 15 \pm 0 \cdot 012$ & $7 \cdot 1 \pm 0 \cdot 8$ \\
Locust cuticle $(1 \%)$ & $0 \cdot 1 \pm 0$ & $0 \cdot 06 \pm 0 \cdot 01$ & $0 \cdot 1 \pm 0$ \\
+cycloheximide $\left(10 \mu \mathrm{g} \mathrm{ml}^{-1}\right)$ & & & \\
\hline \hline
\end{tabular}

* Insoluble crystalline cellulose.

Pro- $\beta$ NA (Fig. 2). The molecular masses of the enzymes were estimated by gel filtration as $M_{\mathrm{r}} 45000$ (aminopeptidase) and 74000 (dipeptidylpeptidase). The resulting preparations of aminopeptidase and dipeptidylpeptidase used in our subsequent experiments were free of co-reactivity (vs Ala- $\beta$ NA or Gly-Pro- $\beta$ NA) and were inactive against substrates for Pr1 (vs Suc-(Ala) ${ }_{2}$-ProPhe- $p$ NA) and Pr2 (vs Ben-Phe-Val-Arg- $p$ NA).

\section{Partial characterization of $M$. anisopliae peptidases}

The effect of $\mathrm{pH}$ on the activity of aminopeptidase and dipeptidylpeptidase was determined using BrittonRobinson buffer over the $\mathrm{pH}$ range 4.5-9.5. The optimum $\mathrm{pHs}$ of aminopeptidase (vs Ala- $\beta \mathrm{NA}$ ) and dipeptidylpeptidase (vs Gly-Pro- $\beta$ NA) were $7 \cdot 0$ and $8 \cdot 0$, respectively (Fig. 3).
The range of activities of aminopeptidase and dipeptidylpeptidase were assessed from the relative rates of hydrolysis of $\beta$ NA substrates (Table 1). Although possessing a very broad specificity, the aminopeptidase had a preference for apolar residues. The best substrate in the series was L-Ala- $\beta \mathrm{NA}$; replacement of the methyl group in alanine by an isopropyl group (valine) or by an $\mathrm{H}$ atom (glycine) substantially decreased hydrolysis. The enzyme was inactive against substrates containing D- or $\beta$-alanine and possessed only trace activity vs Pro- $\beta$ NA and Asp- $\beta$ NA.

The best substrates for the dipeptidylpeptidase contained proline residues in the position penultimate to the free amino acid termini (Gly-Pro- $\beta$ NA and Phe-Pro$\beta$ NA) but a blocked peptide Z-Gly-Pro- $\beta$ NA was not hydrolysed indicating that the enzyme lacks endopeptidase activity. 


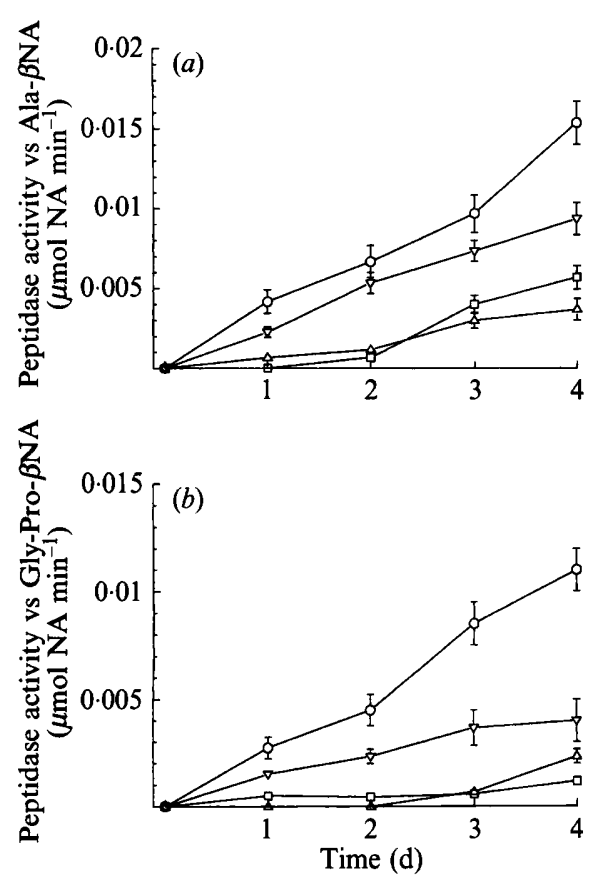

Fig. 4. Production of (a) aminopeptidase (vs Ala- $\beta$ NA) and (b) dipeptidylpeptidase (vs Gly-Pro- $\beta$ NA) in cultures containing $1 \%(w / v)$ locust cuticle $(O)$, or $1 \%(\mathrm{w} / \mathrm{v})$ locust cuticle supplemented with $1 \%$ $(\mathrm{w} / \mathrm{v})$ glucose $(\nabla), 1 \%(\mathrm{w} / \mathrm{v})$ alanine $(\triangle)$ or $0.5 \% \mathrm{NH}_{4} \mathrm{Cl}(\square)$. Each result represents the mean of 3 replicates $\pm S D$. The results are representative of two similar experiments.

Both peptidases were tested for their activity against Ala-Leu-Ala and Ala-Pro-Gly to ensure they were true peptidases and not arylaminidases (Prescott \& Wilkes, 1966). The aminopeptidase hydrolysed Ala-Leu-Ala and Ala-Pro-Gly at the rate of 3 and $0.1 \mu \mathrm{mol}$ amino acids $\mathrm{ml}^{-1} \mathrm{~h}^{-1}$, respectively. The dipeptidylpeptidase lacked activity against Ala-Leu-Ala but hydrolysed Ala-Pro-
Gly $\left(4 \mu \mathrm{mol}\right.$ amino acids $\left.\mathrm{ml}^{-1} \mathrm{~h}^{-1}\right)$. Aminopeptidase activity vs Ala- $p \mathrm{NA}$, (Ala) $)_{2}-p \mathrm{NA}$ and (Ala) ${ }_{3}-p \mathrm{NA}$ were $195,39(20 \%)$ and $5(2.6 \%) \mathrm{nmol} p \mathrm{NA} \mathrm{m} l^{-1} \mathrm{~min}^{-1}$, respectively. Suc-(Ala) $)_{3}-p \mathrm{NA}$ was not hydrolysed indicating that the release of $p$ NA from (Ala) ${ }_{3}-p$ NA occurs via processive hydrolysis of Ala residues.

\section{Effect of inhibitors}

The results of inhibition studies are shown in Table 2. The metal complexing agent 1,10-phenanthroline greatly decreased aminopeptidase activity, indicating that there was a metal ion requirement. Amastatin, an inhibitor of aminopeptidase $\mathrm{A}$ and $\mathrm{M}$, and bestatin against aminopeptidase B and M (Umezawa \& Aoyagi, 1983) also had some inhibitory effect on the $M$. anisopliae enzyme. PMSF and DFP, specific inhibitors for serine proteases, were without effect on the aminopeptidase. By contrast, DFP substantially inhibited the dipeptidylpeptidase. Diprotin A, an inhibitor of dipeptidylpeptidase IV (Umezawa \& Aoyagi, 1983) was also a potent inhibitor of the M. anisopliae dipeptidylpeptidase. Phenanthroline, amastatin, and bestatin were without effect on the dipeptidylpeptidase.

\section{Transfer experiments}

Exponentially growing mycelium was transferred from SDB to MM $\left(0 \cdot 1 \% \mathrm{KH}_{2} \mathrm{PO}_{4}, 0.05 \% \mathrm{MgSO}_{4}\right)$ supplemented with various nutrients (Table 3). Little of the Pr1, aminopeptidase and dipeptidylpeptidase activities were excreted to the medium over $8 \mathrm{~h}$ in media containing $\mathrm{NH}_{4} \mathrm{Cl}$ or glucose. As described previously (St Leger $e t$ $a l ., 1988 b$ ) limitation of carbon and nitrogen (MM) derepressed Pr1 secretion. By contrast, addition of

Table 4. Specific enzyme activities in growth media and permeabilized mycelia

Activities were measured $8 \mathrm{~h}$ after transfer of growing mycelium to medium containing either SDB or $1 \%$ chitin/MM. The activity of Pr1 (vs Suc-(Ala) ${ }_{2}$-Pro-Phe- $p$ NA), aminopeptidase (vs Ala- $p$ NA) and dipeptidylpeptidase (vs Gly-Pro-pNA) is given in nmol $p \mathrm{NA} \mathrm{ml}^{-1} \mathrm{~min}^{-1}$, that of $N$-acetylglucosaminidase is given in $\mathrm{nmol} p$-nitrophenol $\mathrm{ml}^{-1} \mathrm{~h}^{-1}$.

\begin{tabular}{|c|c|c|c|c|c|c|}
\hline \multirow[b]{3}{*}{ Substrate } & \multicolumn{4}{|c|}{ Specific activities [U (mg protein $\left.)^{-1}\right]$} & \multirow{2}{*}{\multicolumn{2}{|c|}{$\begin{array}{l}\text { Activity ratio } \\
\text { filtrate/permeabilized cells }\end{array}$}} \\
\hline & \multicolumn{2}{|c|}{ Culture filtrate } & \multicolumn{2}{|c|}{ Permeabilized cells } & & \\
\hline & $\begin{array}{c}\text { SDB } \\
\text { cultures }\end{array}$ & $\begin{array}{l}\text { Chitin } \\
\text { cultures }\end{array}$ & $\begin{array}{c}\text { SDB } \\
\text { cultures }\end{array}$ & $\begin{array}{l}\text { Chitin } \\
\text { cultures }\end{array}$ & $\begin{array}{c}\text { SDB } \\
\text { cultures }\end{array}$ & $\begin{array}{l}\text { Chitin } \\
\text { cultures }\end{array}$ \\
\hline Ala- $p \mathrm{NA}^{*}$ & $0 \cdot 116$ & $20 \cdot 9 \pm 1 \cdot 10^{*}$ & $<0.1$ & $1.67 \pm 0.06$ & - & $12 \cdot 5$ \\
\hline Gly-Pro- $p$ NA & $0 \cdot 12$ & $1.35 \pm 0.04$ & $0 \cdot 16$ & $0 \cdot 17$ & 0.71 & 7.94 \\
\hline $\begin{array}{l}\text { Suc-(Ala) }{ }_{2}^{-} \\
\text {Pro-Phe- } p \text { NA }\end{array}$ & $<0.1$ & $94 \cdot 5 \pm 4 \cdot 72$ & $<0.1$ & $17 \cdot 6 \pm 1 \cdot 87$ & - & $5 \cdot 37$ \\
\hline $\begin{array}{l}p \text {-Nitrophenyl- } \\
N \text {-acetyl- } \beta \text {-D- } \\
\text { glucosamine }\end{array}$ & $2 \cdot 23 \pm 0.05$ & $11 \cdot 6 \pm 1 \cdot 31$ & $11 \cdot 8 \pm 1 \cdot 52$ & $14 \cdot 1 \pm 1 \cdot 04$ & $0 \cdot 16$ & 0.82 \\
\hline
\end{tabular}

* Mean of three replicates \pm SD. 
insoluble non-repressing protein substrates to $\mathrm{MM}$ was required for secretion of dipeptidylpeptidase. High aminopeptidase activity was only secreted in media containing locust cuticle which was also the optimum substrate for production of dipeptidylpeptidase and Pr1. Secretion of aminopeptidase and dipeptidylpeptidase was repressed when alanine or $\mathrm{NH}_{4} \mathrm{Cl}$ were added to media containing cuticle showing that nitrogen repression overrides the enhancing effect of polymeric substrates (Fig. 4). Glucose was a comparatively ineffective repressing catabolite, indicating that nitrogen sources independently repress production even in the absence of carbon sources. The secretion of extracellular peptidases by mycelium provided with cuticle was probably not due to the release of preformed enzyme molecules since cycloheximide almost completely inhibited enzyme release (Table 3).

\section{Effects of permeabilization}

Evidence that active peptidases are principally extracellular was provided by permeabilization experiments (Table 4). Treatment of mycelia with toluene released only low levels of peptidases as compared with secreted activities detected in growth media. This response was similar to $\operatorname{Pr} 1$, an enzyme which is rapidly secreted from intact cells (St Leger et al., 1988 b). By contrast, toluene treatment released high levels of $\mathrm{N}$-acetylglucosaminidase which is only partially secreted and provides a vesicle marker (St Leger et al., 1988b).

\section{Discussion}

Substrate specificity is an important concern in studies on the biochemistry of peptidases: one substrate can be attacked by more than one enzyme and one enzyme can cleave several substrates (Lojda et al., 1983). Therefore, we initially used analytical electrofocusing to resolve the spectrum of $M$. anisopliae peptidases and to investigate individual peptidases without the need for enzyme purification. The two prolyl-dipeptidylpeptidase bands were clearly distinct from the major aminopeptidase bands. The results reported here also provide evidence that the enzymes are regulated in different ways; prolyldipeptidylpeptidase production was similar in media containing cuticle and casein while aminopeptidase activity was only high in cuticle media. Additional bands in casein cultures which stained with the dipeptidylpeptidase II substrate Lys-Ala-MNA indicate that $M$. anisopliae possesses multiple peptidases as an adaptation to different nutrient conditions.

Transfer experiments confirmed that, compared with other protein substrates, cuticle induced a greater percentage increase in production of aminopeptidase than of the other proteases. Production of aminopeptidase consequently appears more inductive to some factor in insect cuticle than does the more constitutive production of Pr1. Enhanced production of all three enzymes on insect cuticle is consistent with the idea that a major function of extracellular proteases is to make nutrients available from the cuticle. However, our results also suggest that catabolite repression could operate if the release of degradation products from cuticle exceeded fungal requirements. The Prl gene has been cloned and is regulated by repression at the level of mRNA accumulation (St Leger et al., 1992). This implies that the similar repression phenomenon observed here for other peptidases may also be regulated at the level of transcription.

We purified the peptidases to an extent which allowed their partial characterization. In several of its properties, viz. neutral $\mathrm{pH}$ optimum, molecular mass and inhibition by a metal chelating agent, the aminopeptidase activity approximates to the leucine aminopeptidases of some Aspergillus spp. (Lehmann \& Uhlig, 1969; Nakadai et al., 1973). However, the $M$. anisopliae enzyme showed optimum activity against Ala-MNA, indicative of an alanyl aminopeptidase (aminopeptidase $\mathrm{M}$; McDonald, 1985), a classification supported by the partial inhibition of the enzyme by both amastatin and bestatin (Umezawa \& Aoyagi, 1983).

The dipeptidylpeptidase of $M$. anisopliae had a $M_{\mathrm{r}} 74000$ and a $\mathrm{pH}$ optimum of 8 . The $40 \mathrm{kDa}$ membrane bound prolyl-dipeptidylpeptidase (dipeptidyl aminopeptidase ysc IV) of Saccharomyces cerevisiae has a similar pH optimum of 7-7.5 (Alvarez et al., 1985). Both of the fungal enzymes and most of the bacterial prolyldipeptidylpeptidases are sensitive to DFP, implying involvement of a serine residue in catalysis (Khalid \& Marth, 1990). The M. anisopliae enzyme was classified as a prolyl-dipeptidylpeptidase (dipeptidylpeptidase IV) because of its strong preference for substrates having a penultimate proline residue rather than phenylalanine, arginine, or alanine at this position. The yeast enzyme is also inactive against substrates lacking proline, e.g. Ala-Ala-pNA (Alvarez et al., 1985) although bacterial enzymes retain considerable activity against this substrate (Khalid \& Marth, 1990). The M. anisopliae enzyme did not degrade Gly- $\beta$ NA or Pro- $\beta$ NA, precluding the possibility of a stepwise cleavage of Gly-Pro- $\beta$ NA and confirming the importance of the free $\mathrm{N}$-terminal group. This N-terminal position could be occupied by a very small amino acid (glycine) or a residue with a large aromatic side group (phenylalanine) indicating a broad specificity at this subsite. Inhibition of the $M$. anisopliae enzyme by diprotin A, a specific inhibitor of mammalian dipeptidylpeptidase IV (Umezawa \& Aoyagi, 1983), indicates functional similarities with these enzymes. 
The results reported here do not define the precise physiological roles of the exo-peptidases from $M$. anisopliae. In other systems, these enzymes function to release essential amino acids from peptide chains; prolyldipeptidylpeptidases participate in release of proline from proline-rich proteins by further hydrolysing the $\mathrm{N}$ terminal X-Pro-Y-bond (McDonald et al., 1971). The proteolytic and peptidase enzyme systems of $M$. anisopliae [Pr1, Pr2 (St Leger et al., 1987a) aminopeptidase and dipeptidylpeptidase] complement each other in splitting most, if not all, types of peptide bonds. In the absence of the dipeptidylpeptidase, further degradation of $\operatorname{Pr} 1$ and $\operatorname{Pr} 2$ derived cuticle peptides by aminopeptidase would stop at peptide bonds involving proline, thus preventing further hydrolysis by aminopeptidase. Consequently, the aminopeptidase and dipeptidylpeptidase could participate in cuticle degradation as mediators in releasing amino acids which can be utilized as nutrients.

\section{References}

Alvarez, N. G., Bordallo, C., Gascan, S., and Rendueles, P. S. (1985). Purification and characterization of a thermosensitive Xprolyl dipeptidyl aminopeptidase (dipeptidyl aminopeptidase yscIV) from Saccharomyces cerevisiae. Biochimica et Biophysica Acta 832, 119-125.

ANDREWs, P. (1964). Estimation of the molecular weights of proteins by Sephadex gel filtration. Biochemical Journal 91, 222-233.

DoI, E., Shibata, D., \& Matoba, T. (1981). Modified colorimetric ninhydrin methods for peptidase assay. Analytical Biochemistry 118, 173-184.

Goettel, M. S., St Leger, R. J., Rizzo, N. W., Staples, R. C. \& ROBERTS, D. W. (1989). Ultrastructural localization of a cuticledegrading protease produced by the entomopathogenic fungus Metarhizium anisopliae during penetration of host cuticle. Journal of General Microbiology 135, 2233-2239.

Gossrau, R. (1985). Cytochemistry of membrane proteases. Histochemical Journal 17, 737-771.

Hirsch, H. H., Rendueles, P. S., Achstetter, T. \& Wolf, D. H. (1988). Aminopeptidase yscII of yeast. European Journal of Biochemistry 173, 589-598.

Imai, K., Hama, T., \& Kato, T. (1983). Purification and properties of rat brain dipeptidyl aminopeptidase. Journal of Biochemistry 73, 431-437.

Khalid, N. M. \& Marth, E. H. (1990). Purification and partial characterization of a prolyl-dipeptidyl aminopeptidase from Lactobacillus helveticus CNRZ 32. Applied and Environmental Microbiology 56, 381-388.

Laurent, T. C. \& Killander, J. (1964). A theory of gel filtration and its experimental verification. Journal of Chromatography 14, 317-330.

Lehmann, H. \& Uhlig, H. (1969). Aminopeptidesen ans Aspergilli, I. Hoppe-Seyler's Zeitschrift für Physiologische Chemie 350, 99-104.

LoJDA, Z. (1985). The importance of protease histochemistry in pathology. Histochemical Journal 17, 1063-1089.

Lojda, Z., Kulich, J. \& KramL, J. (1983). The usefulness of analytic isoelectric focusing in the histochemistry of enzymes cleaving peptide bonds. Histochemical Journal 15, 294-298.
MCDonALD, J. K. (1985). An overview of protease specificity and catalytic mechanisms: Aspects related to nomenclature and classification. Histochemical Journal 17, 773-785.

McDonald, J. K., Callahan, P. X., Ellis, S. \& Smith, R. E. (1971). Polypeptide degradation by dipeptidyl aminopeptidase I (cathepsin C) and related peptidases. In Tissue Proteinases, pp. 69-107. Edited by A. J. Barrett \& J. T. Dingle. Amsterdam: NorthHolland Publishing.

Nakadai, T., Nasuno, S. \& Iguchi, N. (1973). Purification and properties of leucine aminopeptidase I from Aspergillus oryzae. Agricultural Biology and Chemistry 37, 757-765.

PresCotT, J. M. \& Wilkes, S. H. (1966). Aeromonas aminopeptidase: Purification and some general properties. Archives of Biochemistry and Biophysics 117, 328-336.

Samuels, R., Charnley, A. K. \& St Leger, R. J. (1990). The partial characterization of endoproteases and exoproteases from three species of entomopathogenic entomophthorales and two species of deuteromycetes. Mycopathologia 110, 145-152.

St Leger, R. J., CoOper, R. M. \& Charnley, A. K. (1986a). Cuticledegrading enzymes of entomopathogenic fungi: Cuticle degradation in vitro by enzymes from entomopathogens. Journal of Invertebrate Pathology 47, 167-177.

St Leger, R. J., Charnley, A. K. \& CoOper, R. M. (1986 b). Cuticledegrading enzymes of entomopathogenic fungi: Mechanisms of interaction between pathogen enzymes and insect cuticle. Journal of Invertebrate Pathology 47, 295-302.

St Leger, R. J., Charnley, A. K. \& CoOper, R. M. (1986c). Cuticledegrading enzymes of entomopathogenic fungi: Synthesis in culture on cuticle. Journal of Invertebrate Pathology 48, 85-95.

St Leger, R. J., Charnley, A. K. \& CoOper, R. M. (1987a). Characterization of cuticle-degrading proteases produced by the entomopathogen Metarhizium anisopliae. Archives of Biochemistry and Biophysics 253, 221-232.

St Leger, R. J., CoOper, R. M. \& Charnley, A. K. (1987b) Production of cuticle-degrading enzymes by the entomopathogen Metarhizium anisopliae during infection of cuticles from Calliphora vomitoria and Manduca sexta. Journal of General Microbiology 133, 1371-1382.

St Leger, R. J., CoOper, R. M. \& Charnley, A. K. (1987c). Distribution of chymoelastases and trypsin-like enzymes in five species of entomopathogenic deuteromycetes. Archives of Biochemistry and Biophysics 258, 123-131.

St Leger, R. J., Durrands, P. K., Charnley, A. K. \& CoOper, R. M. $(1988 a)$. Role of extracellular chymoelastase in the virulence of Metarhizium anisopliae for Manduca sexta. Journal of Invertebrate Pathology 52, 285-293.

St Leger, R. J., Durrands, P. K., Cooper, R. M. \& Charnley, A. K. $(1988 b)$. Regulation of production of proteolytic enzymes by the entomopathogenic fungus Metarhizium anisopliae. Archives of Microbiology 150, 413-416.

St Leger, R. J., Butt, T. M., Staples, R. C. \& Roberts, D. W. (1989). Synthesis of proteins including a cuticle-degrading protease during differentiation of the entomopathogenic fungus Metarhizium anisopliae. Experimental Mycology 13, 253-262.

St Leger, R. J., Staples, R. C. \& RoberTs, D. W. (1991). Changes in translatable mRNA species associated with nutrient deprivation and protease synthesis in Metarhizium anisopliae. Journal of General Microbiology 137, 807-815.

St Leger, R. J., Frank, D. C., Roberts, D. W. \& Staples, R. C. (1992). Molecular cloning and regulatory analysis of the cuticledegrading protease structural gene from the entomopathogenic fungus Metarhizium anisopliae. European Journal of Biochemistry 204, 991-1001.

Umezawa, H. \& Aoyagi, T. (1983). Trends in research of low molecular mass protease inhibitors of microbial origin. In Protease Inhibitors: Medical and Biological Aspects, pp. 3-15. Edited by N. Katanuma, H. Umezawa and M. Holzer. Tokyo and Berlin: Japan Science Society Press and Springer-Verlag. 